\title{
O dilema do rebelde: persuasão ou sectarismo
}

Jacques Alkalai Wainberg

Resumo: Este estudo examina o dilema linguístico que o rebelde enfrenta para superar o sectarismo. O exame dos comunicados dos grupos revolucionários que militaram, nas décadas de 1960 e 1970, e de grupos salafistas que atuam agora em várias partes do mundo mostra que seus pronunciamentos demandavam e continuam a demandar inferências interpretativas que o público em geral tinha e tem dificuldade de realizar. Com base nas teorias pragmáticas, é documentado com exemplos variados esse principal obstáculo pragmático à comunicação política de contestação.

Palavras chaves: retórica; pragmática; comunicação política

Abstract: The rebel's dilemma: persuasion or sectarianism - This article examines the linguistic dilemma of the rebel's rhetoric to overcome sectarianism. An analysis of the concepts and discourses presented in the political communiqués of revolutionary groups in the 1960s and 70 s indicates that their publications required and continue to require interpretive inferences that are difficult for the general public to make. This main pragmatic obstacle to contestatory political communication is based on pragmatic theories and documented in various examples.

Keywords: rhetoric; pragmatism; political communication

\section{Apresentação}

O dilema do rebelde é retórico. Através do discurso ele revela suas intenções políticas. Deve-se compreender, por isso, como e de que maneira os grupos rebelados explicam publicamente "suas ações, as ações dos outros e o mundo em volta" (COTTEE, 2010). Através do discurso, o movimento revolucionário procura capturar a atenção do público e fazer-se entender. Ou seja, a audiência deve ser capaz de inferir algo além do dito. Ocorre o oposto quando tais manifestações persuasivas não ecoam na audiência. Os grupos rebelados são descritos como sectários quando seus discursos exortativos são percebidos pelos interlocutores como enigmáticos. 
O dilema do rebelde se expressa no fato de que a pretensão utópica dos grupos revolucionários é radical. Ela exige, por decorrência, um discurso não trivial. Falar aos convertidos é sempre mais fácil. Isso acontece porque esses ouvintes assumem os axiomas dos falantes. Nesse caso, os argumentos são aceitos com base em pressupostos cujas provas estão noutro lugar, geralmente na obra filosófica que dá sustentação ao seu léxico, aos seus conceitos e ao seu discurso. No entanto, caso a barreira entre o dito e o implicado não seja superada pela audiência a própria narrativa estará comprometida.

Como a política não se submete à lógica estrita, mas à retórica, cabe desvendar a vaguidade que usualmente a caracteriza. O sofisma cujo objetivo é produzir uma ilusão de verdade é exemplo desse tipo de vaguidade, produzida por um raciocínio capcioso bastante frequente nas disputas retóricas. Outro exemplo é o raciocínio verossímil cuja conclusão é incompatível com as premissas. Já a lógica não está carregada com este tipo de indefinição. Por isso, mesmo ela pode ser matematizada. Por decorrência, na lógica tudo é explicitado o que permite examinar passo a passo uma proposição. Ou seja, ela independe do contexto para sua decifração. É assim que a lógica sustenta a racionalidade. Sua validade é inconteste e geral.

No entanto, nos embates retóricos torna-se impossível às pessoas avaliarem as condições de verdade de todas as manifestações. Os interlocutores das controvérsias públicas simplesmente assumem certos axiomas. O entendimento deriva do fato de que há um acordo inicial entre falantes e ouvintes sobre os fundamentos dos enunciados. Assim, o que os permite capturar o que permanece implícito nas conversações não está baseado na semântica. A interpretação plena do dito implica em significações que já não tem relação com o conteúdo explícito do texto. Elas dependem, isso sim, do contexto.

A interpretação histórica pode ser vítima desse tipo de armadilha linguística na qual o autor de uma declaração ou de um texto de referência diz algo e o seu leitor de outra época entende do pronunciado um significado inexistente na intenção do discurso original. Em consequência desse "ruído", surgiu o interesse pelos estudos de interface entre a história das ideias e a filosofia da linguagem. Essa interface se consolidou na obra dos historiadores Thomas Peter Rufell Laslett (1991), John Pocock, John Dunn (1983) e Quentin Skinner (1995, 1996, 1997). Juntos eles constituíram uma tradição historiográfica conhecida hoje como Escola de Cambridge. Ela se inspirou principalmente em Wittgenstein (1996), Austin (1975) e Grice (1957). Nessa interface, os clássicos da filosofia política não são considerados atemporais e universais. A significação desses textos canônicos deriva necessariamente do contexto linguístico no qual foram produzidos. É ele que autoriza também o seu léxico.

O estudo hermenêutico visa descobrir os problemas que os textos desejam servir como respostas. O que está em jogo é seu significado, mas não o semântico, e sim o retórico. Essa comunhão do interesse histórico e do estudo da linguagem demanda perguntar, portanto, quais são as intenções que subjazem aos jogos de linguagem utilizados em certa manifestação num determinado ambiente. Cabe recordar que "jogo de linguagem" 
foi um conceito introduzido por Wittgenstein ao fazer a distinção entre a significação e o uso da linguagem. Austin vem a seguir com seu insight sobre os atos de fala. Nessa formulação os enunciados podem ser ações, seja pelo uso de verbos específicos seja em decorrência de sua força ilocutória.

Nesse mesmo sentido, pronunciou-se Grice (1957) ao afirmar que para o falante significar algo com o seu enunciado é necessário que os ouvintes reconheçam sua intenção. O conceito de implicatura por ele proposto, em Logic and Conversation (1975), explica o entendimento inferencial que ocorre entre os falantes e os ouvintes. Como "o implícito não tem forma explícita", a significação plena do que é dito é obtido no contexto. Ou seja, a semântica é relevante somente aos conteúdos literais. Mas ela não é suficiente na análise da significação plena do discurso. A pragmática de Grice afirma que só assim, com essa ajuda decisiva de algo que está fora do âmbito da linguagem, é que o ouvinte pode calcular o que foi plenamente dito pelo falante. Ou seja, é o contexto compartilhado por falantes e ouvintes que oferece as premissas sem as quais as implicaturas conversacionais seriam impossíveis. É o contexto que define também as condições de adequação de uma fala.

Noutra formulação ainda, a de Sperber e Wilson (1996), o contexto considerado é o linguístico. Segundo a Teoria da Relevância, desses autores, a comunicação é um ato ostensivo-inferencial. Ou seja, o falante produz um estímulo que chama a atenção do ouvinte que assim reconhece sua intenção informativa. Quando isso ocorre fica alterado o ambiente cognitivo do receptor. Mas a interação só se torna comunicativa quando ela é bidirecional. Nesse caso, a informação modifica também o ambiente cognitivo do emissor. Segundo Sperber e Wilson, o contexto não é algo externo à interlocução, como proposto originalmente por Grice. Trata-se isso sim de um ambiente cognitivo que é construído durante o ato comunicativo. Falantes e ouvintes podem selecionar e compartilhar suposições.

Por isso mesmo, para superar o sectarismo o grupo rebelado deve necessariamente alcançar esse tipo de competência comunicativa máxima. A conversação será possível se as suposições dos falantes e as dos ouvintes forem comuns. O público é o destinatário que se vê envolvido com as inferências desencadeadas pela ostensão do discurso do rebelado. A partilha de um mesmo ambiente cognitivo permitirá que esse público preste atenção às informações e aos comentários difundidos nos manifestos que lhe pareçam mais relevantes ou relacionados aos seus interesses. Naturalmente, o emissor deverá levar em conta o conhecimento enciclopédico do público receptor. Dessa forma, através desse mecanismo, que aciona com mais facilidade e mais rapidamente esta bagagem predisposta na mente da audiência, o esforço mental para se obter o máximo de benefício cognitivo é menor.

\section{Análise: as inferências discursivas}

A cadeia cognitiva se forma quando informações novas originárias na interlocução se ligam às informações antigas arquivadas na memória dos envolvidos no diálogo, 
exigindo, através da combinação de premissas, o processo inferencial. Assim, por exemplo, a suposição de que a "guerrilha da Europa Ocidental está fazendo o centro imperialista tremer!"1 pode ser assumida pelo interlocutor, seja ele militante ou não do grupo alemão Baader-Meinhof, como verdadeira ou provavelmente verdadeira devido às evidências de sua verdade (o que exigiria apresentação de prova, pouco comum na retórica política), ou à possibilidade de ser verdadeira (nesse caso, o argumento é simplesmente acolhido).

As premissas em jogo são os estímulos ostensivos do falante. No caso, a de que "a ação militar está fazendo o imperialismo tremer". Essa ameaça faz o leitor inferir de que há uma guerra em andamento (nos anos 1970) na Europa. "Guerrilha da Europa Ocidental" é uma designação metafórica. O gap entre seu significado literal e o figurado precisa ser preenchido pelo receptor. Para tanto, o cálculo cognitivo demanda acesso à informação de contexto, ou seja, entender que os jovens rebeldes alemães assim se apresentavam porque desejavam se apropriar da aura revolucionária produzida no Uruguai pelos Tupamaros.

O exemplo analisado mostra a dificuldade que um grupo dissidente enfrenta na sua comunicação política. Isso explica porque os communiqués do Baader Meinhof se destinaram prioritariamente aos que assumiam seus pressupostos ideológicos. Eles chegam a dizer que "não faz sentido explicar a coisa certa às pessoas erradas" ${ }^{2}$. Nesse longo communiqué de 1986, esses militantes se referem à utopia como sendo a derrubada da "estrutura social vigente". Isso seria possível somente através da "luta", que coloca o "sistema em crise". Esse léxico era senso comum entre os rebelados, embora não fosse facilmente decodificado entre os não-iniciados na doutrina marxista. O falante se abstém de apresentar provas e explicitar o dito.

No caso de um manifesto conjunto divulgado na Alemanha, em 1985, pela Ação Direta e a Facção do Exército Vermelho (o nome oficial do grupo Baader-Meinhof), observase que ele é difundido pressupondo a existência de uma profunda crise do capitalismo.

É agora possível lançar uma nova fase no desenvolvimento de uma estratégia revolucionária nos centros imperialistas e criar, como uma condição a um avanço qualitativo à frente, a organização internacional da luta proletária nas metrópoles, com seu núcleo político-militar, a guerrilha da Europa ocidental.

Esse comunicado demanda a unidade dos revolucionários na Europa ocidental. Mas por que naquele exato momento? A resposta não é dada. Ela deve ser simplesmente aceita pelo interlocutor. Infere-se do dito que houve uma velha fase. No entanto, sua explicitação parece ao falante irrelevante. E o que seria "avanço qualitativo à frente"? Trata-se simplesmente de um jargão. Aos não militantes fica difícil compreender porque a "organização internacional da luta proletária nas metrópoles" é um avanço à realização do sonho acalentado, mas não pronunciado e detalhado. Também inexiste prova de que

1 Aos que lutam conosco! Esse comunicado foi divulgado na Alemanha Ocidental em 1986.

2 Build the Red Army! Journal Agit 883, 5 de junho de 1970. 
a "guerrilha da Europa Ocidental" é de fato um agente da redenção social. Ou seja, a linguagem é cifrada. Termos e expressões como nova fase, estratégia revolucionária, avanço, luta proletária, guerrilha da Europa ocidental não são facilmente decodificados pelo observador menos familiarizado com a ideologia que move as ações do grupo.

O parágrafo a seguir vem em socorro do anterior. No entanto, também aqui prepondera a vaguidade. O gap a ser preenchido pelo leitor demanda apelo à informação enciclopédica.

Nós chegamos a esta conclusão como resultado de circunstâncias objetivas: o papel central da Europa Ocidental na reconstrução imperialista no período que se seguiu à derrocada da relação de forças internacionais, como resultado das lutas de libertação no sul e o conflito entre as crescentes capacidades produtivas e o mercado mundial.

Deve-se saber qual é o papel que a Europa Ocidental exerceu na reconstrução do imperialismo logo após a vitória das lutas de libertação no sul. Somente compartilhando uma mesma interpretação da história e de um mesmo léxico (reconstrução imperialista, lutas de libertação no sul, conflito entre capacidades produtivas e o mercado mundial) o receptor poderá inferir o implicado nesse manifesto exortativo.

O próximo exemplo também documenta esse tipo de linguagem cifrada dos manifestos políticos de grupos rebeldes. Trata-se de uma passagem do Mini-Manual da Guerrilha Urbana de Carlos Marighella sobre o revolucionário. O fato de Marighella se interessar em decifrar, nesse documento, os implícitos contidos no termo revela seu desejo "didático" de evitar que os leitores, em especial os próprios simpatizantes de sua causa, tivessem dúvidas. Ele deseja mostrar que desde aquela sua especial circunstância, a da rebelião militar, esse conceito tem um significado profundo que vai bem além do literal. No entanto, a necessidade mesma de sua decifração pelo autor revela também que sua significação não é assumida facilmente pelos interlocutores, em especial os ouvintes que não militam em suas hostes.

O revolucionário é um patriota ardente. Ele luta pela liberdade, ataca o governo, as grandes corporações, os imperialistas estrangeiros, particularmente os americanos, destruindo a propriedade dos ricos. Essa atividade busca criar "uma totalmente nova estrutura social e política revolucionária com o povo armado no poder". O revolucionário é um bravo, preparado em táticas, especialista em armas, munição e equipamento que tem uma alta moralidade. Ele é móvel, um guerreiro que ataca e recua, que não se entrega à fome, fadiga, chuva e calor, que não tem medo de agir de dia ou de noite. Ele é paciente e frio e não se sente desencorajado em levar uma vida normal, mas atuando de fato underground. 


\section{Revolucionário}

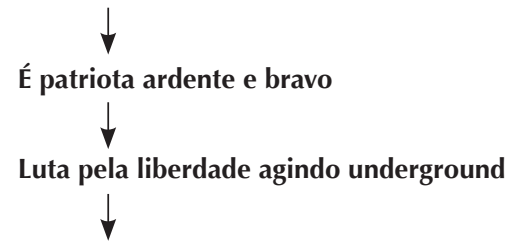

Está preparado em táticas, armas, munição e equipamento

É móvel, ataca as corporações, o governo, os imperialistas e os ricos

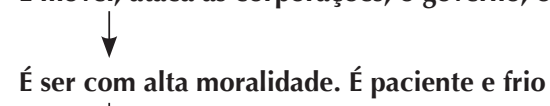

Ataca e recua, não se entrega à fome, fadiga, chuva e calor e não tem medo

Como exposto em Wainberg (2012), o exame através do wordle de dez manifestos divulgados pelos Montoneros, de quinze, difundidos pelo grupo Baader Meinhof ,além de documentos de outros grupos permitiu identificar os verbetes mais frequentes da prosa desses grupos rebelados.

\begin{tabular}{|c|c|c|c|c|c|c|}
\hline Quem fala & $\begin{array}{l}\text { Em nome de } \\
\text { quem se fala } \\
\text { Os Escolhidos }\end{array}$ & $\begin{array}{c}\text { A quem } \\
\text { se destina } \\
\text { a manifestação } \\
\text { A audiência }\end{array}$ & $\begin{array}{l}\text { Quem é o } \\
\text { agente de } \\
\text { mudança } \\
\text { A Vanguarda }\end{array}$ & $\begin{array}{c}\text { Contra quem } \\
\text { se combate } \\
\text { O Inimigo }\end{array}$ & $\begin{array}{l}\text { Como se muda } \\
\text { a realidade } \\
\text { Estratégia }\end{array}$ & $\begin{array}{c}\text { O que se quer } \\
\text { O sonho }\end{array}$ \\
\hline 1. Montoneros & Perón, Pátria & Povo & & Sistema & & $\begin{array}{l}\text { Sociedade } \\
\text { sem classe }\end{array}$ \\
\hline 2. Tupamaros & & Povo (Massas) & Revolucionário & Situação & $\begin{array}{c}\text { Luta ; } \\
\text { Ação política, } \\
\text { movimento, } \\
\text { organização, } \\
\text { forças, armas }\end{array}$ & \\
\hline $\begin{array}{l}\text { 3. Baader- } \\
\text { Meinhof }\end{array}$ & Trabalhadores & $\begin{array}{c}\text { Povo } \\
\text { (estudantes) }\end{array}$ & Revolucionário & Sistema & $\begin{array}{l}\text { Luta (guerrilha; } \\
\text { Resistência) }\end{array}$ & $\begin{array}{l}\text { Sociedade } \\
\text { sem classe }\end{array}$ \\
\hline $\begin{array}{l}\text { 4. Dissidência } \\
\text { comunista e } \\
\text { outros (Brasil) }\end{array}$ & Proletariado & Povo (massas) & Revolucionário & $\begin{array}{c}\text { Burguesia, } \\
\text { Ditadura }\end{array}$ & Luta & \\
\hline $\begin{array}{c}\text { 5. Partido } \\
\text { Revolucionário } \\
\text { dos } \\
\text { Trabalhadores } \\
\text { (Trotskista } \\
\text { Argentina) }\end{array}$ & & Massas/partido & Revolucionário & Militares & $\begin{array}{c}\text { Guerra/ Luta } \\
\text { armada }\end{array}$ & \\
\hline
\end{tabular}

Quadro 1: Os verbetes mais frequentes no discurso político dos grupos rebelados nos anos 1960 
Esse Quadro 1 revela uma estrutura similar do discurso rebelado. Há um ator a ser rendido pela ação política. Ela define uma audiência privilegiada. Escolhe o agente revolucionário e um alvo a ser combatido. Por fim, apresenta a estratégia de luta e o sonho a ser realizado.

Visando a sua comprovação, esse quadro é comparado com outro que emerge de estudo similar realizado com uma amostra de documentos salafistas composto por 17 cartas da Al Qaeda, apreendidas no refúgio de Osama Bin Laden, no Paquistão, e que foram selecionadas pelo exército norte-americano para divulgação. O wordle revela que irmãos/irmandade é mencionado 527 vezes nestes textos, Deus/Allah, 428 vezes; povo, 254; muçulmano, 171; islâmico, 310; mujahidin, 204; inimigo, 94; jihad, 165 e Islã, 68. Essa amostra contém ainda os cinco artigos escritos por Al Maqdese mais acessados por leitores no site Tawheed ${ }^{3}$ e dos três artigos mais lidos nesse portal pelo público (escritos por Hussein Bin Mahmoud, Lion of Jihad e Akram Hijazi).

Constata-se que a retórica jihadista/salafista está fortemente marcada, em ordem decrescente, pelos verbetes Alá, povo, Deus, muçulmano, profeta, religião e paz. Outra maneira ainda de documentar o discurso salafista/jihadista contemporâneo é submeter ao wordle manifestações públicas de pregadores religiosos e de personalidades políticas veiculadas na televisão e em vídeos postados na internet. As fontes utilizadas nesse exame são o discurso de Mohamed Morsi durante as eleições egípcias; ${ }^{4}$ a manifestação pública de milhares de salafistas na Tunísia - Obama, nós todos somos Osama; ${ }^{5}$ manifestação do clérigo Hashem Islam Ali, da Universidade islâmica Al-Azhar; ${ }^{6}$ manifestação de Saud Al-Fanisan, ex-diretor da Faculdade de Direito Islâmico da Universidade saudita; ${ }^{7}$ e a pregação pelo extermínio de judeus e americanos, proferida por Ahmad Bahr do Hamas ${ }^{8}$. Os verbetes mais frequentes nessas manifestações foram Alá (36 vezes), Maomé (6), Alcorão(6), shaaria (6), jihad (6), liberdade (5), multidão, islâmico e povo (4).

3 The Response of Sheik Abu Muhammad Al-Maqdese to the Letter from the Mujahid Sheikh Abu Musaab Abdu; Is it possible for a Rafidi (Shia) to spill one drop of blood to free Al Aaqsa mosque?; Why do we hate them?; An advice for the American msulims; And so that the way of the sinners may become Manifest; A message in support of the Mujahideen in Somalia

4 A Jihad é o nosso caminho, a morte em nome de Alá é nossa mais elevada aspiração, a Shaaria é nossa constituição 13/maio/2012, Misr 25 TV.

5 Postado na internet em 20 de maio de 2012.

6 Os ataques suicidas são um dever religioso (Al Aqsa TV, 27 de julho de 2012)

7 A lei islâmica permite a possessão de escravos, Al-Risala TV, 16 de março de 2012.

8 Al-Aqsa TV, 10 de agosto de 2012. 


\begin{tabular}{|c|c|c|c|c|c|c|}
\hline Quem fala & $\begin{array}{l}\text { Em nome de } \\
\text { quem se fala } \\
\text { Os Escolhidos }\end{array}$ & $\begin{array}{c}\text { A quem se } \\
\text { destina a } \\
\text { manifestação } \\
\text { A audiência }\end{array}$ & $\begin{array}{l}\text { Quem é o } \\
\text { agente de } \\
\text { mudança } \\
\text { A Vanguarda }\end{array}$ & $\begin{array}{l}\text { Contra quem } \\
\text { se combate } \\
\text { O Inimigo }\end{array}$ & $\begin{array}{c}\text { Como se } \\
\text { muda a } \\
\text { realidade } \\
\text { Estratégia }\end{array}$ & $\begin{array}{c}\text { O que se quer } \\
\text { O sonho }\end{array}$ \\
\hline $\begin{array}{l}\text { 6. Al Qaeda } \\
\text { correspondên- } \\
\text { cia interna }\end{array}$ & Alá & $\begin{array}{c}\text { Irmãos, } \\
\text { Irmandande, } \\
\text { Povo }\end{array}$ & Mujahidin & Inimigo & $\begin{array}{l}\text { Jihad } \\
\text { Guerra }\end{array}$ & $\begin{array}{c}\text { Islã } \\
\text { Islâmico } \\
\text { Muçulmano } \\
\text { Paz }\end{array}$ \\
\hline $\begin{array}{l}\text { 7. Discursos } \\
\text { salafistas/jiha- } \\
\text { distas }\end{array}$ & Alá & $\begin{array}{c}\text { Povo, Massa, } \\
\text { Povo }\end{array}$ & & & $\begin{array}{c}\text { Jihad, Shaaria, } \\
\text { Alcorão }\end{array}$ & $\begin{array}{l}\text { Islâmico, } \\
\text { Liberdade }\end{array}$ \\
\hline $\begin{array}{c}\text { 8. Salafismo/ } \\
\text { Jihadismo }\end{array}$ & Alá, Maomé & $\begin{array}{c}\text { Povo } \\
\text { (Muçulmano) }\end{array}$ & & & & \\
\hline
\end{tabular}

Quadro 2: Os verbetes mais frequentes no discurso salafista

Ou seja, os Quadros 1 e 2 sugerem a existência de uma propriedade geral do discurso revolucionário: ele é marcado não só por um léxico similar como também por uma estrutura comum. O mesmo pode ser observado em documentos adicionais dispersos no tempo, como revela o Quadro 3. Ele inclui O Manifesto Comunista de Karl Marx; o capítulo "Doutrina e Partido" do livro Minha Luta de Adolfo Hitler; o Manual da Insurreição Armada escrito por Louis Auguste Blanqui (1866); A Guerra Retardada, divulgada por Mao Tse Tung, em 1938, e o primeiro editorial do jornal Moudjahid, publicado pela Frente Nacional de Libertação (FNL) da Argélia em 1956.

O léxico apresentado nesse quadro e que se repete nos variados discursos dos grupos rebeldes parece operar como um mantra e como tal visa em última instância produzir um efeito psicoativo no receptor. Essa retórica persuasiva é reforçada ainda por gritos de guerra do tipo "Perón ou Morte", utilizado pelos Montoneros na Argentina, e "Alá é Grande", como ocorre entre os militantes dos grupos salafistas. 


\begin{tabular}{|c|c|c|c|c|c|c|}
\hline Quem fala & $\begin{array}{l}\text { Em nome de } \\
\text { quem se luta }\end{array}$ & $\begin{array}{c}\begin{array}{c}\text { Para quem } \\
\text { se apela }\end{array} \\
\text { A audiência }\end{array}$ & $\begin{array}{c}\text { Quem é } \\
\text { o agente da } \\
\text { mudança }\end{array}$ & $\begin{array}{c}\text { Contra quem } \\
\text { se combate }\end{array}$ & $\begin{array}{c}\text { Como se } \\
\text { muda a } \\
\text { realidade }\end{array}$ & $\begin{array}{c}\text { O que se quer } \\
\text { O sonho }\end{array}$ \\
\hline $\begin{array}{l}\text { 9. Manifesto } \\
\text { comunista, } \\
\text { K. Marx }\end{array}$ & $\begin{array}{c}\text { Proletariado } \\
\text { Operário }\end{array}$ & Sociedade & Revolucionário & Burguesia & $\begin{array}{c}\text { Luta } \\
\text { Revolução }\end{array}$ & $\begin{array}{l}\text { Comunismo } \\
\text { Socialismo }\end{array}$ \\
\hline $\begin{array}{l}\text { 10. Minha } \\
\text { Luta, A. Hitler } \\
\text { Segunda Parte, } \\
\text { Doutrina e } \\
\text { Partido }\end{array}$ & $\begin{array}{l}\text { Estado } \\
\text { Alemanha } \\
\text { Reich } \\
\text { Raça } \\
\text { Alemão }\end{array}$ & $\begin{array}{l}\text { Povo } \\
\text { Nação } \\
\text { Massas }\end{array}$ & $\begin{array}{l}\text { Movimento } \\
\text { Partido }\end{array}$ & Judeus & $\begin{array}{l}\text { Luta } \\
\text { Guerra }\end{array}$ & \\
\hline $\begin{array}{l}\text { 11. Manual } \\
\text { da Insurreição } \\
\text { Armada de } \\
\text { Louis Auguste } \\
\text { Blanqui }\end{array}$ & & Povo & Insurreição & Exército & $\begin{array}{l}\text { Luta } \\
\text { Barricadas }\end{array}$ & \\
\hline $\begin{array}{c}\text { 12. A guerra } \\
\text { Retardada, } \\
\text { Mao Tse Tung, } \\
1938\end{array}$ & Povo & Povo & & O inimigo & $\begin{array}{c}\text { Guerra } \\
\text { guerrilha }\end{array}$ & \\
\hline $\begin{array}{c}\text { 13. Editorial } \\
\text { da primeira } \\
\text { edição } \\
\text { do jornal } \\
\text { Moudjahid, } \\
\text { Argélia, 1956, } \\
\text { FNL }\end{array}$ & Povo & Combatentes & Guerra & & & Vitória \\
\hline
\end{tabular}

Quadro 3: O léxico revolucionário: Marx, Hitler, Blanqui, Mao Tse Tung e FNL

Tais exortações foram intensamente utilizadas ao longo de toda a história. Exemplos são "Nobiscum Deus" ("Deus está conosco", utilizado pelos exércitos cristãos do império romano e bizantino); "Caelum Denique" ("Finalmente o Céu", utilizado pelos cruzados na Terra Santa); "Dieu Le veut" ("Deus o Quer", utilizado pelos cruzados franceses); "Desperta ferro!" (grito de guerra usado pelos Almogávares - forças mercenárias que serviram na infantaria ligeira da Coroa de Aragão nos séculos XIII e XIV); "Terra e Liberdade" (utilizado pelos soldados de Emilio Zapata no México); "hurra" (derivado do verbo "matar" em turco e utilizado por vários exércitos, entre eles o russo e o britânico) e "banzai" (repetido pelos pilotos camicases japoneses na Segunda Guerra Mundial).

Ou seja, os gritos de guerra são "atos de fala" que visam reforçar o "espírito de corpo" de certa "irmandade". Eles desejam despertar ora a fé dos militantes e ora sua 
agressão contra os inimigos. Visa também intimidar com o medo o campo opositor. No passado, esse efeito era amplificado por instrumentos acústicos variados, como cornetas, tambores, gaita de foles, música marcial e trompas de caça.

\section{O contágio mental e a narrativa de senso comum}

O que está em jogo na ação comunicativa dos grupos rebelados é a capacidade de sua narrativa se "espalhar" amplamente num certo ambiente, tornando-se então senso comum. Essa propriedade pragmática tem sido destacada pelos teóricos da narratologia. Através das histórias, as pessoas organizam suas experiências e as tornam pública. Tal formulação não é nem aleatória nem ingênua. (MOTA, 2009) Na verdade, a narrativa institui a realidade ao "produzir certos efeitos de sentido" no receptor (Ibid). Portanto, nessa perspectiva, as histórias narradas podem ser consideradas também como "atos de fala". Contamos histórias para interpretar os eventos, para produzir sentido das ocorrências e apontar os personagens de um drama, o plot que os envolve, o desenlace e - o mais importante - o seu ensinamento.

O efeito epidêmico dessas histórias foi relatado e realçado em Fights, Games, and Debates por Anatol Rapoport (1970). Segundo esse autor, a epidemia social depende de um contato direto de um indivíduo com um "vetor" contaminado. No caso, a "doença" é certa atitude, um comportamento ou alguma informação. Se não ocorrer alguma ação de defesa do corpo social à narrativa interpretada como ameaçadora, por hipótese todo ser vivo daquele sistema poderá ser atingido pela "infecção".

Obviamente, isso não ocorre porque há uma "imunidade natural" - nem todos expostos ao vetor (a história propriamente dita) contrairão a "doença". O indivíduo "contaminado" ficará "doente" por algum tempo, mas não por todo o tempo. Ele poderá se recuperar ou então "morrer". Há também pessoas que estão "imunes". Esse fato contribui à queda na virulência da sua disseminação. Além disso, o isolamento dos membros da comunidade (quarentena) ao "vetor" ajudará na diminuição da "epidemia".

Outra forma de prevenção ainda é a imunização. Antecipando-se aos perigos da mensagem persuasiva que se avizinha, o amplo sistema educacional pode proporcionar estímulos capazes de provocar na audiência o despertar de anticorpos mentais. O que está em jogo no caso da formação de uma opinião pública é o "número crítico" dos "contaminados". Se esse número ultrapassar certo limite a infecção avançará vigorosamente até se consolidar como senso comum. Caso contrário, poderá diminuir.

O matemático e físico Lewis Fry Richardson referiu-se igualmente a esse fenômeno em War Moods (1948). Ele dizia que há contágio quando algumas pessoas imitam outras pessoas. Nesse caso, certo padrão de comportamento ocorre. Esta propagação com multiplicação (epidemia) é então possível. Ele refere vários estágios: a existência de um estado de "incubação" de certa disposição, um "estado infectado, mas não infeccioso", o estágio da "recuperação" e o desaparecimento da "infecção".

Sperber (2011) também elaborou sobre a "epidemiologia das representações". Ele explica que a epidemiologia estuda a distribuição de certos itens na população. No caso desse 
estudo, trata-se da capacidade que certa forma de pensamento possui de se alastrar em certa comunidade. Em sua visão, nós registramos o que as palavras transmitidas significam como maneira de descobrir algo mais profundo, o estado mental do emissor. Em sua opinião, as declarações não são capazes de codificar plenamente nossos pensamentos, embora sejam capazes de apontar pistas sobre eles. Ou seja, como proposto, a propriedade pragmática envolvida nesse processo é a inferência. E a representação plena do comunicado pelo emissor deriva de fatores de contexto partilhados com o receptor. A cognição é um fenômeno que ocorre no cérebro das pessoas, numa situação e em rede (ibid.).

O conceito de "contágio mental" adquire relevância porque é útil na decifração de inúmeros fenômenos sociais que derivam em larga medida do conteúdo difundido através dos meios massivos de comunicação. Ele foi bastante referido nas obras de memórias dos militantes brasileiros, dos anos 1960 e 1770, que destacaram o papel que a televisão exerceu na difusão das rebeliões dos estudantes, realizadas em várias partes do mundo naquele período (WAINBERG, 2010)

\section{O estilo do discurso}

Como são infinitas as possibilidades de uso da linguagem, cabe precisar ainda o estilo retórico dos enunciados. Vale dizer que a cada forma retórica corresponde certo efeito de sentido no conteúdo. A escolha de uma forma retórica pelo falante revela as suposições que ele faz das habilidades cognitivas do ouvinte assim como dos recursos de contexto disponíveis à significação de mensagem.

Usualmente o estilo emotivo é o predominante na retórica política. É verdade que à exceção do cálculo matemático todas as formas de manifestação humana estão carregadas de graus distintos de emoção, até mesmo a prosa científica (que se esforça em evitá-la). Mas o caso da propaganda política é similar ao da poesia. Em ambos a carga emotiva é forte e a semântica mais fraca. Tais palavras e expressões emotivas, muitas delas metafóricas, são estímulos ostensivos que servem de atalho à mente e ao comportamento das pessoas.

O cálculo pragmático do que é dito com estas expressões singulares evoca o amplo debate teórico sobre a existência (ou não) de um glossário emocional universal. Segundo a linguista Anna Wierbicka, "as evidências sugerem que em todas as culturas as pessoas distinguem linguisticamente (e lexicalmente) entre diferentes tipos de sentimentos" (WIERBICKA,1999).

Assim, dada uma mesma carga semântica, mas variando a carga emocional do discurso, há efeitos distintos de conexão entre falantes e ouvintes. Por exemplo, ela pode ser obtida com a ajuda de um discurso polido que estimula o interlocutor a "baixar a guarda".

O linguista britânico Geoffrey Leech (1983) estabeleceu seis máximas da polidez conversacional: o tato, a generosidade, a aprovação, a modéstia, o acordo e a simpatia. A polidez expressa a intenção de um interlocutor em salvar as aparências frente a manifestações que lhe são dirigidas numa conversação através de palavras ou modos 
de expressão (o tom e outros signos não verbais). Exemplos são as ameaças, alertas, conselhos, demandas, raiva, desculpas, insultos, acusações, reclamações, uso de gírias e jargões, e humilhação. Certamente, efeito oposto é causado quando o discurso é descortês, como é o caso do uso do palavrão e do xingamento (PAIL, 2012).

Hoje em dia, através do Topsy ${ }^{9}$, é possível avaliar nas conversações dos tuiteiros o grau de apreço existente ao glossário rebelde apresentado. Observa-se na tabela 5, a seguir, que vários conceitos dos anos 1960 ainda desfrutam de estima popular. São os casos de "revolução" e de "revolucionário", por exemplo, "guerrilha" sofreu algum desgaste. O mesmo ocorreu com "Perón". Ou seja, embora a maior parte do diálogo virtual de 2013 seja opaca em relação ao léxico rebelde dos anos 1960 e 1970, observa-se, entre os que tuitam em seu favor, avaliações bem positivas.

\begin{tabular}{|c|c|c|c|}
\hline Termo & Sentimento (de zero a 100) & $N^{0}$ de tweets positivos & $N^{o}$ de tweets negativos \\
\hline Revolução & 74 & 1.354 .817 & 898.619 \\
\hline Revolucionário & 63 & 286.735 & 269.272 \\
\hline Revolução social & 59 & 2.831 & 1.576 \\
\hline Perón & 57 & 13.966 & 11.710 \\
\hline Guerrilha & 53 & 47.961 & 40.276 \\
\hline Revolução política & 51 & 463 & 528 \\
\hline Luta armada & 15 & 284 & 2.972 \\
\hline
\end{tabular}

Quadro 4: Grau de estima aos marcadores retóricos dos anos 1960 e 1970 nos tweets em todo o mundo. Fonte: Topsy. 21/01/2012 a 21/01/2013

\section{Considerações finais}

Os manifestos dos grupos rebelados são utilizados como armas de uma luta retórica que visa, em última instância, à persuasão do ouvinte. Como os objetivos políticos dos grupos rebelados são dissonantes o seu discurso não é (e não pode ser) trivial. Esse fato exige do público muito mais do que uma interpretação literal do dito nesses manifestos. A narrativa rebelde será vitoriosa se vencer tal obstáculo pragmático à comunicação. Só então ela será capaz de se "espalhar", indo de mente em mente até se tornar um novo senso comum.

Os exemplos analisados sugerem que em geral os comunicados políticos dos grupos com pretensão revolucionária fazem uso de (1) um léxico similar; (2) evocam uma audiência preferencial; (3) definem um objetivo militante; (4) apelam a uma vanguarda; (5) definem uma estratégia de luta (usualmente violenta) e (6) apontam um inimigo a ser combatido. Além do mais, utilizam a emoção como uma espécie de "lubrificante social" que facilita sua difusão.

9 http://topsy.com 


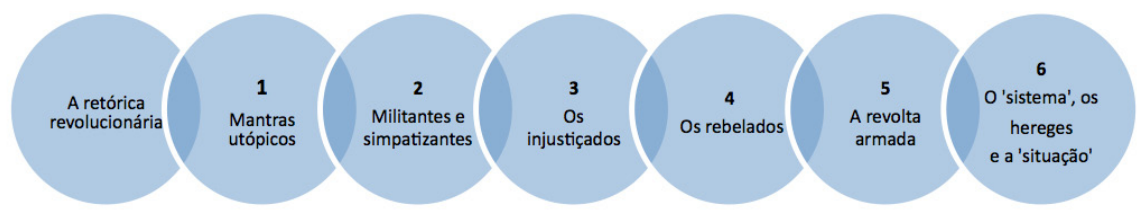

O dilema do rebelde é retórico no sentido de que ele deve compartilhar com o público não só um mesmo ambiente linguístico como também pressupostos ideológicos.

Pode-se afirmar também que numa parcela significativa da opinião pública de hoje persiste um apreço e um interesse ao glossário rebelde dos anos 1960 e 1970. O mesmo ocorre com o vocabulário salafista, que propõe agora uma revolução islâmica que vise, em última instância, uma nova utopia, o renascimento do califado e o reinado da shaaria em todo o mundo. Esse fato explica porque Alá é agora o termo mais tuitado e retuitado no mundo.

\begin{tabular}{|c|c|c|c|c|c|c|c|c|c|}
\hline & Revolução & Rev. Social & $\begin{array}{c}\text { Rev. } \\
\text { Política }\end{array}$ & $\begin{array}{c}\text { Rev. } \\
\text { Islâmica }\end{array}$ & $\begin{array}{l}\text { Revolucio- } \\
\text { nário }\end{array}$ & Jihad & Guerrilha & Alá & $\begin{array}{c}\text { Luta } \\
\text { armada }\end{array}$ \\
\hline MUNDO & 7.803 .960 & 15.138 & 3.854 & 9.181 & 1.538 .609 & 1.090 .109 & 616,448 & 134.725 .551 & 5.136 \\
\hline USA & 4.261 .567 & 10.048 & 2.335 & 5,661 & 1.114 .620 & 495.548 & 192.341 & 13.818 .715 & 3.037 \\
\hline Japão & 702.541 & - & - & - & 21.209 & 10.369 & 15.979 & 238.186 & \\
\hline UK & 443.367 & 1.199 & 222 & 629 & 94.539 & 40.362 & 17.043 & 1.109 .766 & 396 \\
\hline Brasil & 304.254 & 371 & 83 & 158 & 32.068 & 15.708 & 28.815 & 429.462 & 70 \\
\hline França & 249.713 & - & - & - & - & 13.211 & & 1.048 .955 & \\
\hline Canadá & 102.117 & 344 & 50 & 95 & 20.440 & 6.757 & - & - & 45 \\
\hline México & 95.226 & 144 & 27 & - & 16.302 & - & 37.050 & - & \\
\hline Itália & 79.483 & 252 & - & - & 13.581 & - & - & - & 43 \\
\hline Turquia & 79.067 & & 45 & 172 & 18.460 & 6.495 & - & 20.364 .115 & 146 \\
\hline Índia & - & 393 & 453 & 120 & 17.074 & 12.222 & - & - & 135 \\
\hline Áf. do Sul & - & 250 & 44 & - & 21.856 & - & - & - & 332 \\
\hline Austrália & - & 176 & - & - & - & - & - & - & \\
\hline Rússia & - & - & - & 129 & - & - & - & - & - \\
\hline Egito & - & - & - & 116 & - & - & - & - & - \\
\hline Colômbia & - & - & - & - & - & - & 142.164 & - & - \\
\hline
\end{tabular}

Quadro 5: Países que mais tuitam e retuitam sobre as nove temáticas selecionadas. Por número de tweets.

Fonte: Topsy. 21/01/2012 a 21/01/2013 
Jacques Alkalai Wainberg é professor titular do Programa de Comunicação da PUC-RS.

jacqalwa@pucrs.br

\section{Referências}

AUSTIN, John Langshaw. How to do things with words. Harvad: Harvard University, 1975.

COTTEE, Simon. Mind Slaughter: the neutralizations of jihadi salafism. Studies in Conflict and Terrorism, n. 33, 2010.

DUNN, John. The political thought of John Locke. Cambridge: Cambridge University Press, 1983.

GRICE, Herbert Paul. Meaning. The Philosophical Review, v. 66, n.3, jul, 1957.

"Logic and Conversation". In: Syntax and semantics 3: Speech arts. pp. 41-58, 1975.

LASLETT, Thomas P. R.. Patriarcha and other Political Writings. Cambridge: Cambridge University Press, 1991.

LEECH, G. Principles of pragmatics. London, New York: Longman Group Ltd, 1983.

MOTA. Luiz Gonzaga. Narrativas: representação, instituição ou experimentação da realidade? SBPJOR, ENCONTRO NACIONAL DE PESQUISADORES EM JORNALISMO, 7. Anais... São Paulo, USP, 2009.

PAIL, Daisy Batista. A retórica da polidez e dos palavrões nas redes sociais: uma abordagem por interfaces. Dissertação de Mestrado, Instituto de Letras, PUCRS, 2012.

RAPOPORT, Anatol. Fights, Games and Debates. Michigan, The University of Michigan, 1970.

RICHARDSON, Lewis Fry. War Moods. Psychometrika, v. 13, n. 3-4, sept-dec, 1948.

SKINNER, Quentin. Maquiavelo. Madrid: Alianza, 1995.

As fundações do pensamento político moderno. São Paulo: Cia das Letras, 1996.

Razão e Retórica na filosofia de Hobbes. São Paulo: Unesp, 1997.

SPERBER, Dan. A naturalistic ontology for mechanistic explanations in the social sciences. Cambridge: Cambridge University Press, 2011.

;WILSON, Deirdre. Relevance: Communication and Cognition. Cambridge: Blackwell, 1996.

WAINBERG, Jacques A. O embate pelo controle da memória traumática brasileira. Texto (online), v. 2,2010 .

A revolução, a luta, a resistência e o povo: os marcadores retóricos dos anos 60. Revista Brasileira de Ciências da Comunicação, v. 35, n. 1, jan/jun, 2012.

WIERBICKA, Anna. Emotional Universals. Language Design, n. 2, 1999.

WITTGENSTEIN, Ludwig. Investigações Filosóficas. São Paulo: Nova Cultural, 1996. 